\title{
Evaluation of Seasonal Effects of Tillage and Drainage Management Practices on Soil Physical Properties and Infiltration Characteristics in a Silt-Loam Soil
}

\author{
Rifat Akis ${ }^{1 *}$, Rattan $\mathrm{Lal}^{2}$

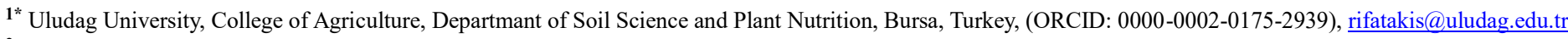 \\ 2 Ohio State University, Colege of Food Agriculture and Environment, School of Environment and Natral Resources, Soil Science, Colubus, OH, USA, (ORCID: 0000- \\ 0002-9016-2972), la11@osu.edu
}

(International Conference on Design, Research and Development (RDCONF) 2021 - 15-18 December 2021)

(DOI: 10.31590/ejosat.1050860)

ATIF/REFERENCE: Akis, R. \& Lal, R. (2021). Evaluation of Seasonal Effects of Tillage and Drainage Management Practices on Soil Physical Properties and Infiltration Characteristics in a Silt-Loam Soil. European Journal of Science and Technology, (32), 10111023.

\begin{abstract}
The impacts of tillage and drainage managements on soil infiltration characteristics need to be scrutinized for a better understanding and prediction of soil hydrological processes, such as runoff, evapotranspration and soil water storage. The objectives of this study were i) to evaluate the effects of tillage and drainage practices on soil physical properties and water infiltration, and ii) to compare prediction accuracy of estimated and optimized infiltration model characteristics for the observed and predicted quantities of infiltration process in the soil. The research site contains the Crosby-Kokomo soil series (fine, mixed, mesic, Aeric Ochraqualf and fine, mixed, mesic Typic Argiaquoll, respectively). The experiment was a two factorial completely randomized block design with two levels of tillage (chisel plow $(\mathrm{CH})$ and no-till (NT)) and two levels of drainage (drained (D) and undrained (UD)) with three replicates. Soil bulk density ( $\rho_{\mathrm{b}}$ ), saturated hydraulic conductivity $\left(\mathrm{K}_{\text {sat }}\right)$, soil moisture retention curves (SMRC), soil infiltration capacity and piezometric water head in each treatment were also measured. Soil drainage flows at each drain lateral and outlet discharges were measured. The results showed that The UD treatments were always higher for Ksat values than the D treatments regardless of the tillage practices for both depths and the $\mathrm{CH}$ treatments always had greater Ksat values than those in the NT at both the depths regardless of drainage practices. The D treatments reduced the soil bulk density by 4.2 and $0.8 \%$ in the surface soil and 4.61 and $6.7 \%$ for the subsurface soil in respect to notill-UD and chisel-UD treatments. The UD treatments had higher bulk density at both of the depths than those of the D treatments regardless of tillage practices except the CH-UD treatments. The NT had higher bulk density at both depths of the soil than those of the $\mathrm{CH}$ treatments regardless of drainage practices. Drainage increased pore size distribution significantly higher than the UD treatments $(\mathrm{p}<0.05)$. The $\mathrm{D}$ treatments had significantly higher storage pores and effective pores $(9.37 \%)$ (pores retaining water at $-10 \mathrm{kPa}$ pressure head) than the ones in the UD treatments $(8.96 \%)(\mathrm{p}<0.05)$. The NT treatments yielded higher infiltration rates than the $\mathrm{CH}$ and the D treatments produced higher apparent infiltration rates and cumulative infiltration values than the UDs. The changes in soil physical properties were found to be strongly and significantly dependent on season, soil depth, and rainfall $(\mathrm{p}<0.05)$. The optimized infiltration models predicted larger range of infiltration rate values for each treatment than the estimated infiltration models, indicating that the optimization produced higher accuracy and validity of the predicted models in the field. To conclude, soil dry bulk density, soil saturated hydraulic conductivity, and increased macropore volumes can significantly impact soil hydrological responses to soil water infiltration, soil water storage and drainage flow under conservation tillage and drainage management practices on a seasonal basis. This impact enhances greater potential to capture water in soil for future crop use in the study site.
\end{abstract}

Keywords: Tillage, Drainage, Infiltration.

\section{Tillage ve Drainage Yönetim Sistemlerinin Siltli-Tınlı Bir Toprağın Fiziksel Özelliklerine ve Infiltrasyonu Üzerine Etkilerinin İncelenmesi}

Öz

Yüzey akış, buharlaşma-terleme, ve toprak su tutma kapasitesi gibi toprak hidrolojik süreçlerinin daha iyi tahmin edilmesi ve anlaşılması için toprak işleme ve drenaj yönetiminin toprakta infiltrasyon karekteristiklerine etkilerinin araştırılmasına ihtiyaç duyulmaktadır. Bu çalışmanın amaçları i) toprak işleme ve drenaj tekniklerinin toprak fiziksel özelliklerine ve toprakta infiltrasyona etkilerini izlemek ve ii) deneme parsellerinden ölçümlerle üretilen infiltrasyon modellerinin tahmin süreçlerindeki hassasiyetlerinin tahminci model ve 
optimize edilen model arasında karşılaştırmaktır. Araştırmanın yapıldığı arazi Crosby-Kokomo toprak serileri (ince, karışık, mezik, Aerik Okrakualf (havalanma problemi olmayan okrik epipedona sahip sıklıkla su basmasına maruz kalan Alfısol) ve ince, karışık, mezik, sıklıkla su basmasına maruz kalan tipik arcillik horizonlu Mollisol) büyük toprak guruplarını içermektedir. Deneme deseni üç paralelli, ikişer doza sahip, iki toprak işleme ve iki drenaj faktörünü içeren 2-faktöriyel rastgele deneme deseni olup, deneme konuları (çizel işleme $(\mathrm{CH})$, sıfır işleme (NT) ve drenajlı (D) ve drenajsız (UD)) parsellerden meydana gelmektedir. Toprak kuru hacim ağırlığı $\left(\rho_{\mathrm{b}}\right)$, doygunluk hidrolik iletkenlik değeri (Ksat), toprak nem karakteristik eğrisi (SWRC), süzme kapasitesi ve piyezometrik su yükü seviyesi her parselde ölçülmüştür. Toprak drenaj debileri parsellerdeki her lateral boruda ve drenaj sistem çıkış ağzında ölçülmüştür. Araştırma sonuçları her iki toprak işleme yöntemi içerisinde her iki toprak derinliğinde de drenajsız uygulamaların drenajlı uygulamalara göre her zaman daha yüksek Ksat değerine sahip olduklarını göstermiştir. Her iki drenaj uygulaması içerisinde her iki derinlik için yapılan karşılaştırmada çizel parseller sıfır işleme parsellerinden her zaman daha büyük Ksat değerlerine sahip olmuşlardır. Yüzey toprağında drenajlı parseller toprak hacim ağırlığını sırasıyla sıfır işleme+drenajsız uygulama parsellerinde \% $4,2-0,8$ kadar düşürürken, yüzey altı toprak katmanında (15-30 cm katmanı) çizel+drenajsız parsellerde \%4,61-6,7 kadar azaltmıştır. Çizel+drenajsız parseller hariç, drenajsız uygulamalar her iki derinlik katmanında da drenajlı uygulamalara göre bütün toprak işleme parsellerinde daha yüksek kuru hacim ağırlığı değerine sahip olmuştur. Sıfır işleme+drenaj uygulamaları çizel toprak işlemeye göre her iki toprak derinliğinde de daha yüksek kuru hacim ağırlığı değerlerine sahiptirler. Drenaj parselleri drenajsız parsellere göre gözenek çapı dağılımını önemli derecede artırmıştır $(\mathrm{p}<0,05)$. Drenajlı parseller $(\% 9.37)$ drenajsız parsellere $(\% 8.96)$ göre önemli miktarda daha fazla depo por ve etkili por $(-$ $10 \mathrm{kPa}$ negatif basınçta su dolu porlar) hacmine sahip bulunmuştur $(\mathrm{p}<0.05)$. Sıfır işlemeli parseller çizel parsellere göre daha anlık yüksek infiltrasyon değerlerine sahip olmuştur ve drenajlı parseller drenajsız parsellere göre daha yüksek infiltrasyon oranı ve eklemeli infiltrasyon değerlerine sahip olmuşlardır. Toprak fiziksel özelliklerinde meydana gelen değişimler güçlü bir şekilde ve önemli derecede mevsime, toprak derinliğine ve yağış miktarlarına bağlı olduğu görülmektedir $(p<0,05)$. Optimize edilmiş infiltrasyon modelleri her bir deneme konusu için tahminci modele göre daha geniş bir aralığı tahmin etme özelliğine sahip oldukları görülmüştür. Buda gösteriyor ki optimizasyon süreci tarla ölçümleriyle elde edilen tahminci modelden daha yüksek hassasiyet ve geçerlilik derecesine sahiptir. Sonuç olarak, toprak kuru hacim ağırlığı, Ksat, yüksek makropor miktarları, toprağın infiltrasyon oranları, su tutma kapasitesi ve drenaj debilerine karşı tepkisini mevsimsel olarak korumalı tarım ve drenaj etkisi altında önemli derecede etkileyebilmekte ve bu etki nedeniyle korumalı tarım ve drenaj pratikleri daha çok su tutma potansiyeli tetiklemektedir/geliştirmektedir.

Anahtar Kelimeler: Toprak İşleme, Drenaj, Süzme.

\section{Introduction}

Soil physical properties are considered as the main controls on water infiltration to soil and other hydraulic properties upon determining soil water potentials. As a result, infiltration characteristics of a soil are in close relationships with initial moisture content, soil bulk density, porosity, particle size distribution and stable aggregate percentage as well as other structural indices. Jastrow and Miller (1991) reports management of soil structural parameters is a progression to improve soil structural indices, i.e., total porosity and bulk density, and water infiltration processes that is governed by soil water flow characteristics such as soil saturated hydraulic conductivity and its proxy of constant infiltration rate in soil. Slaking and dispersion of macropres are common observations in quick wetted soil structure, resulting in clogging of pores, poor aeration, less infiltration and impaired hydraulically conductive conditions in soil (Lal et al., 1989; Jastrow and Miller, 1991; Lal and Fausey, 1993) that are very commonly coexistent properties with poorlyand very poorly-drained soils. In general, poor drainage conditions are characterized as less porous, slow and very slow hydraulically conductive, very week structural stability, highly dense conditions, and inadequate aeration in soil because of high water table or impervious layer in the soil profile.

The NT farming can be adopted to improve soil drainage conditions, depth to water table, water table management, infiltration capacity which is a critical parameter for water table recharge, and aeration by conserving soil structure by adding more porosity and organic matter and minimizing soil erosion (Soane et al., 2012). In fact, tillage practices necessitate to couple with subsurface drainage to improve soil physical properties minimizing soil sediment transport and erosion in somewhat poorly- and very poorly-drained soils (Randall and Iragavarapu, 1995). Managing soil drainage is crucially important to enhance crop yield and physical soil properties under no-till (Abid and Lal, 2008). Artificially drained land under conservation farming lacks adequate research and scientific data to improve operational decision making for similar subfield management of soil physical properties. Abid and Lal (2009) reported no-till and artificial drainage research needed more attention for a better soil physical quality. No-till increased Ksat in the subsoil, infiltration rate, stable and vertical pores in the soil and stabilized root channels and earthworm burrows resulting in increased Ks (Soane et al., 2012).

Infiltration rate is sensitive to soil moisture availability, dry bulk density, texture and their intreactions with plant (Angelaki et al., 2013), soil management practices, water retention characteristics, porosity (Nakajima and Lal, 2014) field capacity, wilting point, surface runoff generation, and soil aggregation (Irmak et al, 2011; de Almeida et al., 2018), soil physical properties, precipitation, canopy cover, and antecedent moisture content, (Czyzyk and Swierkot, 2017; Abid and Lal, 2009; Nakajima and Lal, 2014), land use type (Thornley and Cannell, 2000; de Ameida et al., 2018) and, soil tillage and surface roughness (de Almeida et al., 2018). Soil infiltration is more impacted by land use type /land use change than by soil tillage (de Almaida et al., 2018).

The NT registered greater infiltration rate and cumulative infiltration depth against the $\mathrm{CH}$ and moldboard till in a typic argiaquoll silty clay loam soil, classed as Kokomo series with a very poorly drained quality in the central Ohio (Shkula et al., 2003). McGarry et al. (2000) reported the NT practices increased soil water storage and infiltration. Soil tillage effects are reported on a seasonal basis for the increases in macropores and decreases in macropore volume, stability and continuity (Roseberg and McCoy, 1992). Increases in bulk density because of tillage operations after a long period of time and deterioration of 
infiltration rate and available water capacity were also reeported (Franzluebbers, 2002).

Soils under the NT produces more porosity because of developed soil structure and therefore, higher infiltration capacity and macropore flow than conventional tillage (Goddard et al., 2008; Huang et al., 2015). Massing and Jarvis (1993) found wetting and drying cycles resulted in increased volume of macropres from their tilled clay soil by their tension infiltrometermeasured macro- and meso porosity at matric potentials of $-4 \mathrm{~cm}$ and $-6 \mathrm{~cm}$. Kutílek et al. (2006) observed that the entisol soil samples under short range compression (0-300 kPa) showed structural and matrix pore size change because of less developed structure, while the Alfisol soil samples registered the change in the structural pores owing to their well-developed structure. They concluded that increases in compression stress did not produce uniform pore size changes and their effective pore size was yet small enough $\left(2.5 \mu \mathrm{m}<\mathrm{r}_{\text {effective }}<10.5 \mu \mathrm{m}\right)$ to prevent water retention parameters from complete deterioration.

Tillage operations disrupt soil aggregates resulting in surface crust because of dispersion of clay and amount of soil moisture (Kay, 1990). Crusting and compaction developed in Chisel till and moldboard plowing against the NT (Freese et al., 1993). Crop residue cover in the NT lowered bulk density and crusting while significantly increasing infiltration (Dao, 1993) and water retention time (Derpsch et al., 2014). Sediment transport and surface crusting under the effects of raindrop in a conventional tillage experiment were apparent shortly after tillage operations in Brasil because of inadequate vegetation cover, low porosity and decreased infiltration rate (Carvalho et al., 2015).

Response of soil physical properties to infiltration process in conservation tillage practices is vitally important to manage soil erosion and hydrologic components of irrigation, drainage, and soil water storage. Replenishment of soil moisture content, recharge in groundwater resources, and management of drainage water and system layout in the field requires infiltration monitoring and modeling in soils. Soil tillage significantly alters soil physical and hydrological properties. These properties govern infiltration rate as a function of soil saturated hydraulic conductivity and pore size distribution, which have been strongly related to wetting front penetrations in infiltration process, and thus final infiltration rate becomes closely related to the soil saturated hydraulic conductivity. As a result, infiltration process is inexorable component of water management plans and projects in the field of agriculture and its hydrology. Infiltration rates impacted the efficiency and uniformity of water spread both in surface and root zone soil (Rahsidi et al., 2014), drainage characteristics and optimization of plant water available capacity in soil (Adeniji et al., 2013). Rather than monitoring and measuring instant infiltration processes over a spatially variable landscape, prediction models and equations for an accurate representation of water infiltration have been developed and modified widely. The validity, applicability and predictability of these models have been still researched under various field conditions.

The prediction accuracy of soil infiltration models has recently been tested in several studies. Mahapatra et al. (2020) reported $99 \%$ of best fit of Philip infiltration model estimated values to the observed values. Gopi and Shanmugasundaram (2019) observed the best fit of infiltration data to the Philip's equation under similar initial water content conditions. The
Philip's equation was found more accurate to estimate infiltration depth to the soil (Rajasekhar et al., 2018). Khasraei et al. (2021) analyzed six infiltration models for their accuracy in wheat and bean cultivation systems by using nonlinear regression method and they observed the Philip's equation was the best for estimating cumulative infiltration depth in their study. Dashtaki et al (2009) compared several infiltration models to each other in Iran to match the best model with their research sites. They concluded that the Kostiakov-Lewis model was best suited to their measured data. Jha et al. (2019) measured sorptivity and transmissivity terms from infiltration rate curve and cumulative infiltration curve for all treatments. Their coefficient of variation ranged between 6 and $40 \%$ for sorptivity in the experimental plot level and $333 \%$ and infinity for the experimental field level. Their cumulative infiltration curve was much better than infiltration rate curve to determine soil sorptivity and transmissivity. Their field spatial variability of infiltration was high and more sampling was indispensable duty to reach a common $\mathrm{CV}$ values in their field. Infiltration modeling studies mentioned above conclude that the infiltration process is seasonally, scale, and spatial dependent in the field conditions and its measurements are needed for a sound local and watershed level water budget development through hydrologic modeling.

Therefore, the objectives of this study were i) evaluate the effects of tillage and drainage practices on soil physical properties and water infiltration, and ii) to compare prediction accuracy of estimated and optimized infiltration model characteristics for the observed and predicted quantities of infiltration process in the soil.

\section{Material and Method}

\subsection{Site Specific Field Description}

The Kenny Road Farm of the Ohio State University, Columbus, $\mathrm{OH},\left(40^{\circ} 02^{\prime \prime} 00^{\prime \prime} \mathrm{N}, 83^{\circ} 02^{\prime \prime} 30^{\prime \prime} \mathrm{W}\right)$ was used to conduct this research project for two consecutive years from 1996 to 1998. The soil at the research site was Silt Loam with a moderately deep soil profile and poor- and very poorly-drained conditions, containing the Crosby and Kokomo soil series (fine, mixed, mesic, Aeric Ochraqualf and fine, mixed, mesic, typic Argiaquoll, respectively, (Soil Survey Staff, 1996). These soils are typically developed on the Wisconsin till plane the $30-60 \mathrm{~cm}$ layer frequently manifest a 'Clay bulge' yielding to subdividing the Argillic horizon into $\mathrm{Bt} 1$ and $\mathrm{Bt} 2$ regardless of the research area. Further, more than half of the area had a soil profile with Bt3 horizon (Sullivan, 1997). The parent material in the experimental site was registered to be glacial till The means of annual precipitation and air temperature were respectively reported as $1016 \mathrm{~mm}$ and $11{ }^{\circ} \mathrm{C}$ (USDA-NRCS, 2006 and Abid and Lal, 2009). Two factorial complete randomized block design with three replicas was applied to the field for the experimental design. Two factors of drainage (drained and undrained plots) and two factors of tillage (no till and chisel till) were combined into the tillage and drainage combinations of no-till drained (NTD), notill undrained (NTUD), chisel-drained (CHD) and chiselundrained (CHUD) treatments. Total research area was 1 ha, consisting of 12 plots of $28 \mathrm{~m} \mathrm{x} 28 \mathrm{~m}$ each. Six treatment plots had tile pipe drainage system while the rest was undrained plots. The chisel tillage plots were furrowed via chisel tiller in the Fall season and disking in the Spring season for the seedbed preparation practices, while the no-tilller was used in the Spring 
for seeding the no-till plots in the research site. The plots were separated/buffered by a 5-6 $\mathrm{m}$ grassed road strip lines for field trafficability, operations, and runoff flow reductions from plot to plot in wet seasons. Continuous corn plantation (Zea mays L.) has been established in the research site as it was for long years.

The tile drainage system was laid out in the field with drain depth and spacing specification of $1 \mathrm{~m}$ and $9 \mathrm{~m}$, respectively and pipe size was designed to be $100 \mathrm{~mm}$ perforated and corrugated plastic pipe with three laterals in each drainage plot. Each of the drainage plot had a sump on the centerline of downstream edge of drainage plot, situating on the middle lateral pipe. Field laterals connected to main drainage pipes that drained into open ditch or stream approximately $50 \mathrm{~m}$ away from the research site. Tile flow rates and total volumes of drainage flow discharges were recorded via a utility type water gauge fixed to the open end of middle drainpipe in each sump in the drained plot. More details of the tile drainage system technical specifications can be found in Sullivan (1997) and Abid and Lal (2009).

\subsection{Soil Physical and Hydraulic Properties}

Bulk density (Blake and Hartge, 1986), water retention characteristics (Klute, 1986), and saturated hydraulic conductivity (Ks) (Klute and Dirksen, 1986) were determined in undisturbed soil core samples of $7.6 \mathrm{~cm} \times 7.6 \mathrm{~cm}$ for both depths in the treatments. All soil physical properties were determined on the seasonal basis. These measurements for both $0-15 \mathrm{~cm}$ and 15-30 $\mathrm{cm}$ layeres with two parallels were repeated for 3 consecutive seasons, spring, summer, and fall. The middle point of drain laterals was located for the core samples within the interrows in each plot at each sampling time. A specific caution was exercised to avoid sampling on the drain lines in the field at all times of sampling. Sampling was performed when the soil was at about moisture content less than or equal to field capacity so that the soil samples could have been avoided compacting upon sampling.

\subsection{Soil Water Release Curves and Distribution of Pore Sizes}

Water release curves (WRC) relates soil volumetric water content to soil water potential. The undisturbed cores were also used in determining soil saturated hydraulic conductivity and diffusivity (Klute and Dirksen, 1986) in the laboratory with constant head permeameter. Darcy's law was applied to measure saturated hydraulic conductivity, hydraulic gradient, flux density, and volume flux per time.

Soil water retention was measured for higher soil water potentials at $0 \mathrm{kPa},-3 \mathrm{kPa},-6 \mathrm{kPa}$ on tension table. On the other hand, the lower water potentials such as $-10 \mathrm{kPa},-30 \mathrm{kPa},-60 \mathrm{kPa}$, $-100 \mathrm{kPa}$, and $-1500 \mathrm{kPa}$ were determined on the pressure plate apparatus (Klute, 1986). It took 3-4 days for soil cores to reach equilibrium. Volumetric soil moisture content was determined by gravimetric moisture content by multiplying soil specific gravity $\left(\mathrm{cm}^{3} \cdot \mathrm{cm}^{-3}\right)$ for each measured soil water potential.

Availabel water was the depth product of the difference between moisture potentials at $-100 \mathrm{kPa}$ and $-1500 \mathrm{kPa}$ (Cassel and Nielsen 1986).

Water release curve was employed to compute soil pore diameters (PSD) for moisture range of saturation $(0 \mathrm{kPa})$ and permanent wilting point $(-1500 \mathrm{kPa})$. The equivalent pore e-ISSN: 2148-2683 diameter (EDP) $(\mu \mathrm{m})$ drained at negative pressure of $\psi(\mathrm{kPa})$ was obtained by the equation 300/ $\psi$ (Marshall and Holmes, 1988). The volume of drained pores between 0 and $3 \mathrm{kPa}$ was an estimate of macropores, $-3-6 \mathrm{kPa}(100-50 \mu \mathrm{m})$ as transmission pores, and $10 \mathrm{kPa}-1500 \mathrm{kPa}(30-0.2 \mu \mathrm{m})$ as storage pores (Greenland, 1979). Total pore volume (ft) and porosity were computed from dry bulk density $\left(\rho_{b}\right)$ and particle density $\left(\rho_{s}\right)$ as $f_{t}=\left(1-\rho_{b} / \rho_{s}\right)$. Similarly, air filled porosity was calculated as $f_{a}=\left(f_{t}\right.$ - volumetric water content at field capacity).

\subsection{Infiltration Model and Measurements}

Double ring infiltrometer technique (Bouwer, 1986) was used to perform infiltration test, conducted once after the harvesting of corn in autumn 1997. The double rings consisted of 24 and $15 \mathrm{~cm}$ diameters for the outer and inner ring, respectively. Two measurements were conducted at each treatment plot rather than runoff plots. The inner cylinder was subdivided by a centimeter based ruler so that head declines in the cylinder of smaller size was easily monitored in timely basis. The treatments varied in achieving a constant infiltration values and therefore, the testing was terminated at different times of durations for each treatment. During the test, cumulative elapsed time (minute), head difference during the readings $(\mathrm{mm})$, cumulative infiltration depth, and infiltration rate $\left(\mathrm{cm} \cdot \mathrm{min}^{-1}\right)$ were the main recording as the test continued. The infiltration time series data were analyzed according to Philip (1957). A straight line for infiltration rate (i vs. $\left.\mathrm{t}^{-1 / 2}\right)$ and a $\log$ - $\log$ scale plot $(\log I$ vs $\log \mathrm{t})$ for the cumulative infiltration depth were fitted to the data.

In Philip (1957),

$$
\begin{aligned}
& I=S t^{1 / 2}+A t \\
& i=\frac{1}{2} S t^{-1 / 2}+A
\end{aligned}
$$

where I denote cumulative infiltration $(\mathrm{cm}), \mathrm{S}$ is soil sorptivity, A is transmissivity, and $t$ is the elapsed cumulative time in hour.

A spreadsheet analysis was used to obtain the infiltration parameters, the initial infiltration rate $\left(i_{i}\right), S, A$, and $I$, from the field measurments and These measurements were fitted to the derivative $(d I / d t)$ for each treatment. The corresponding model parameters were optimized through Excel Solver extension by using the nonlinear optimization procedure of generalized reduced gradient (GRD) method. The solver with this method puts control on the slope of the penalty/objective function as the input variables are read into the solver to find the optimum solution. In the optimization process, steady state infiltration rate values, which are considered as a realization of saturated field hydraulic conductivity values, were given special attention in order not to be a negative value. The optimization logic was employed by letting the change of instant infiltration rate and elapsed time values in order for finding optimal $\mathrm{i}_{\mathrm{i}}, \mathrm{S}, \mathrm{A}$, and I value upon minimizing the variability between the estimated and optimized model outputs according to a penalty function $(\mathrm{P})$ as follows:

$$
P=\sum_{i=1}^{n}\left(\text { Observed }_{i}-\text { Estimated }_{i}\right)^{2}
$$


These estimated and optimized parameters and models were validated by a different infiltration time series dataset collected from the same treatments at the same sampling time. The indexed observed- and estimated- values correspond to infiltration rate or accumulative infiltration depth, respectively, $\mathrm{n}$ is the total number of measured or estimated time series value of points in infiltration process.

\subsubsection{Analysis of Infiltration Model Performance}

Prediction accuracy of infiltration model was determined by estimated and optimized infiltration model parameters. Root mean squared error (RMSE) and Nash-Sutcliffe efficiency (NSE) determined if the model can be used within the limits of measured time series of infiltration data in the site and whether or not the models are valid which will allow the applicability of the models in the filed-scale estimations of infiltration event. In other words, a lower RMSE and a higher NSE indicate a higher prediction accuracy for the predicted and the observed value in the dataset of infiltration test. The RMSE values should be close to zero so that a higher model validity occurs. On the other hand, the NSE values should be between zero and one for a valid model, out of the range of which is accepted as poorly predicting characteristics of a model.

\subsubsection{Statistical Analysis of the Field Soil Physical Properties and Infiltration Tests}

Two-way analysis of variance (ANOVA) procedure tested the interactions between the treatments using MINITAB Version 17.0. The ANOVA test does not tell which variance value of the variables is significant when the variance of the mean is significant. Therefore, different tests for the means should be used to clearly state which mean has a significant variance in the test. The assumptions of two-way ANOVA such as normality, constant variance, and independent random samples were checked out to proceed with this statistical procedure through normality and residual plots, respectively. Based on these plots, a transformation of the data was carried out if necessary. Then, the data were tested to estimate main effects.

When the main effects existed, Fisher's least significant difference (LSD) test was performed on the data using a level of significance $(\alpha=0.05)$ for each ANOVA test, performing pairwise comparison between the means tested. The null hypotheses of the ANOVA and thus the Fisher's LSD test were the same, stating that the difference of means were equal to zero. Otherwise, alternative hypotheses were accepted at $5 \%$ level of significance.

\section{Results and Discussion}

\subsection{Soil Physical Properties}

There were no significant effects of tillage $\mathrm{x}$ drainage interactions and main effects on soil Ksat values at both of the depths in soil (Table 1). As a result, main effects of each factor was analyzed on the soil Ksat and bulk density. Regardless of tillage treatments, soil saturated hydraulic conductivity values for two depths were found to be always higher in the UD plots than those from the $\mathrm{D}$ plots during the research period. The UD treatments yielded approximately 61 and $113.3 \%$ greater Ksat values for the surface layer and 152 and $6 \%$ for the subsurface layer, respectively for NT and $\mathrm{CH}$ treatments. Similarly, the Ks values for two depths in the $\mathrm{CH}$ plots were always greater than the ones from the NT plots regardless of drainage practices (Table $1)$.

\section{Table 1. Effects of tillage and drainage on soil Ksat and bulk density at two depths}

\begin{tabular}{|c|c|c|c|c|c|c|}
\hline \multirow{2}{*}{$\begin{array}{l}\text { Treat- } \\
\text { ments }\end{array}$} & \multicolumn{3}{|c|}{ Ksat0-15cm } & \multicolumn{3}{|c|}{ Ksat15-30cm } \\
\hline & NT & $\mathrm{CH}$ & $\begin{array}{c}\mathrm{p}- \\
\text { value }\end{array}$ & NT & $\mathrm{CH}$ & $\begin{array}{c}\text { p- } \\
\text { value }\end{array}$ \\
\hline $\mathrm{D}$ & $0.56 \mathrm{a}$ & $3.32 \mathrm{a}$ & 0.244 & $1.66 \mathrm{a}$ & $5.17 \mathrm{a}$ & 0.376 \\
\hline UD & $0.89 a$ & $7.08 \mathrm{a}$ & 0.389 & $4.18 \mathrm{a}$ & $5.48 \mathrm{a}$ & 0.383 \\
\hline p-value & 0.558 & 0.605 & & 0.527 & 0.959 & \\
\hline \multicolumn{7}{|c|}{ Analysis of Variance $\mathrm{P}>\mathrm{F}$} \\
\hline Tillage & 0.22 & & & 0.498 & & \\
\hline Drainage & 0.56 & & & 0.687 & & \\
\hline \multirow[t]{2}{*}{$\begin{array}{l}\text { Tillage } \mathrm{x} \\
\text { Drainage }\end{array}$} & 0.625 & & & 0.753 & & \\
\hline & & $\rho_{\mathrm{b} 0-15 \mathrm{~cm}}$ & & & $\rho_{\mathrm{b} 15-30 \mathrm{cr}}$ & \\
\hline $\mathrm{D}$ & $1.34 \mathrm{a}$ & $1.32 \mathrm{a}$ & 0.880 & $1.36 \mathrm{a}$ & $1.34 \mathrm{a}$ & 0.818 \\
\hline UD & $1.40 \mathrm{a}$ & $1.31 \mathrm{a}$ & 0.456 & $1.43 \mathrm{a}$ & $1.40 \mathrm{a}$ & 0.800 \\
\hline p-value & 0.652 & 0.954 & & 0.619 & 0.614 & \\
\hline Tillage & 0.567 & & & 0.726 & & \\
\hline Drainage & 0.822 & & & 0.465 & & \\
\hline $\begin{array}{l}\text { Tillage } \mathrm{x} \\
\text { Drainage }\end{array}$ & 0.749 & & & 1.000 & & \\
\hline
\end{tabular}

An insignificant reduction in soil dry bulk density in all drained treatments at both soil depths was observed in comparison to undrained treatments because of the drainage system in the field (Table 1). Drained treatments reduced the soil bulk density by 4.2 and $0.8 \%$ in the surface soil and 4.61 and $6.7 \%$ for the subsurface soil in respect to NT-UD and CH-UD treatments. The value $0.8 \%$ represents an experimental error because of truncation errors mostly from 3 digits to two digits after comma and very close values were measured. This result persists in the same soil tillage and drainage treatment plots monitored by Nakajima and Lal (2014) for the $0-10 \mathrm{~cm}$ and $10-20 \mathrm{~cm}$ depth intervals. It is clear that drainage have a long term constraint on soil variability and the variability has been reduced by soil drainage. In fact, this outcome is itself a management decision support for the research field provided by the drainage system that can be used to decide whether to increase residue remnants on the surface soil to prevent from soil erosion and sediment transport to the streams.

The main effects of individual tillage and drainage management practices may be concealed by some other factors that were not measured or determined in the experimental design of research study. Considering season as a factor to include in the randomized factorial block design, variability in the soil physical properties can be elaborated better than it was elaborated based on just tillage and drainage treatments in the field. Table 2 illustrates that treatment (tillage, drainage), depth $(0-15 \mathrm{~cm}$ layer, $15-30 \mathrm{~cm}$ layer), and season (spring, summer, fall) were tested for their effects on soil Ksat and bulk density in a completely randomized factorial block design. Since the season has three levels, the analysis is called multilevel factorial analysis. On the other hand, depth, tillage and drainage possess two levels and their analyses are called 2-factorial and 2-level analysis in the 
frame of 2-factorial randomized block design analysis in Minitab 17 statistical package. The treatments composed of tillage and drainage and the tillage factor is composed of only the NT and the $\mathrm{CH}$ plots, while the drainage factor is constituted by the collection of the D and the UD plots in this multilevel analysis. Therefore, the analysis employed the factors and their levels as follows: 2level of treatments (tillage, drainage), 2-level of depth $(0-15 \mathrm{~cm}$, $15-30 \mathrm{~cm}$ ), and 3-level of season (spring, summer, fall).

Table 2 shows that the tillage practices gained more water conductive and less dense soil conditions in comparison to drainage practices. Although these effects on the soil Ksat and bulk density are not significant among treatments $(\mathrm{p}=0.084)$, tillage and drainage system in the field intrinsically tended to produce the result abovementioned. The results are exactly the same as mentioned in Table 1 when depth-effect on the Ksat and $\rho b$ is elaborated (Table 2). The season implemented the most important impact on the soil Ksat $(\mathrm{p}=0.006)$ and $\rho b(\mathrm{p}=0.000)$ values under different managements practices (Table 2). As a consequence, the behaviors of soil Ksat and $\rho b$ under different tillage and drainage are season dependent and variability of soil $\rho b$ is more seasonal dependent than the one for soil Ksat in the research field. Besides, the compound term, treatment, consisting of individual tillage plots and individual drainage plots seems to be seasonally more effective on soil $\rho b(p=0.087)$ than the factor of soil depth $(p=0.125)$. The Ksat means of treatments were significantly different from each other $(p=0.001)$ and the fall values of Ksat were significantly higher than the rest of the seasonal Ksat values. The Ksat sequences in the ascending order spring $<$ summer $<$ fall. The soil $\rho b$ values varied significantly between the seasons $(p=0.000)$. Summer bulk density values are significantly higher than the others. Soil dry bulk density lies in the descending order fall $<$ spring $<$ summer. Hernandez et al. (2019) reported similar sequence of bulk density values in their soils in Ohio. No significant differences in the effects of interaction terms were observed. Both soil Ksat and $\rho b$ values behave in the same fashion being in parallel to the behavior of rainfall recharge period in the region. The recharge period covers fall-winter-spring seasons in the research site and the summer is pretty dry for at least 4 months. The fall precipitations provided hydraulically-conductive flow conditions in the soil that carried the Ksat to its highest value in the season. More hydraulicallyconductive soil conditions require good structural stability and aggregation and less dense and highly porous conditions. As a result, the highest Ksat in the fall overlaps the lowest $\rho b$ values in the research field after harvest. Soil losses considerably large amount of water and soil becomes more compacted and small hydraulic conductivity values take the charge to conduct air and water in the soil in summer. As a result, soil bulk density grows larger in the summer in the field. Bhattacharyya et al. (2009) reported increases in bulk density in the NT treatments for the surface soil layer in comparison with the $\mathrm{CH}$ treatments. Huang et al. (2015) observed decreases in soil bulk density for their 0-20 $\mathrm{cm}$ soil under no-till practices and compared these declines against their chisel treatment, concluding that NT treatments reduced bulk density as they received organic matter amendments while the effect was more severe in the conventional tillage treatments. Significant differences in bulk density in surface soil of 0 to $10 \mathrm{~cm}$ layer was observed as a result of short durations of times such as weeks (Osunbitan et al., 2005). de Silva et al. (2012) observed the $\mathrm{CH}$ treatments prevailed smaller bulk density values than the NT treatments.
Table 2. The effect of treatment, depth, season and their interactions on the soil Ksat and $\rho_{b}$

\begin{tabular}{|c|c|c|}
\hline Treatment & Ksat & $\mathbf{p b}$ \\
\hline \multirow{2}{*}{ Tillage Drainage } & $4.41 \mathrm{a}$ & $1.34 \mathrm{a}$ \\
\hline & $2.68 \mathrm{a}$ & $1.39 \mathrm{a}$ \\
\hline \multicolumn{3}{|c|}{ Analysis of Variance $\mathrm{P}>\mathrm{F}$} \\
\hline Treatment & 0.442 & 0.46 \\
\hline \multicolumn{3}{|l|}{ Depth } \\
\hline \multirow{2}{*}{$\begin{array}{l}\mathrm{d}_{0-15 \mathrm{~cm}} \\
\mathrm{~d}_{15-30 \mathrm{~cm}}\end{array}$} & $2.96 \mathrm{a}$ & $1.35 \mathrm{a}$ \\
\hline & $4.12 \mathrm{a}$ & $1.38 \mathrm{a}$ \\
\hline \multicolumn{3}{|c|}{ Analysis of Variance $\mathrm{P}>\mathrm{F}$} \\
\hline Depth & 0.608 & 0.512 \\
\hline \multicolumn{3}{|l|}{ Season } \\
\hline Spring & $0.03 \mathrm{~b}$ & $1.29 \mathrm{~b}$ \\
\hline Summer & $1.93 \mathrm{~b}$ & $1.54 \mathrm{a}$ \\
\hline Autumn & $8.67 \mathrm{a}$ & $1.27 \mathrm{~b}$ \\
\hline \multicolumn{3}{|c|}{ Analysis of Variance $\mathrm{P}>\mathrm{F}$} \\
\hline Season & 0.001 & 0.000 \\
\hline \multicolumn{3}{|c|}{ Analysis of Variance of the Linear Model $\mathrm{P}>\mathrm{F}$} \\
\hline Treatment & 0.361 & 0.087 \\
\hline Depth & 0.537 & 0.125 \\
\hline Season & 0.006 & 0.000 \\
\hline Treatment x Depth & 0.865 & 0.407 \\
\hline $\begin{array}{l}\text { Treatment } \mathrm{x} \\
\text { Season }\end{array}$ & 0.272 & 0.304 \\
\hline Depth x Season & 0.810 & 0.537 \\
\hline $\begin{array}{l}\text { Treatment x Depth } \\
\mathrm{x} \text { Season }\end{array}$ & 0.992 & 0.551 \\
\hline
\end{tabular}

Table 3 shows pore size classes according to the soil moisture characteristic curve for each soil depth. The PSD was classified in three classes based on equivalent pore radius: transmission pores with $<50 \mu \mathrm{m}$ equivalent pore radius, storage pores with $0.2 \mu \mathrm{m}$ $<\mathrm{r}<50 \mu \mathrm{m}$, and micropores with $<0.2 \mu \mathrm{m}$ (Lal and Shukula, 2004). 
European Journal of Science and Technology

Table 3. Effects of tillage and drainage on pore size distribution for the 0-15 and 15-30 cm layers of the soil

\begin{tabular}{|c|c|c|c|c|c|c|c|c|}
\hline \multirow{2}{*}{$\begin{array}{l}\text { Treatments } \\
\text { Drainage }\end{array}$} & \multicolumn{6}{|c|}{ Soil pore size distribution for the $0-15 \mathrm{~cm}$ layer } & \multirow[b]{2}{*}{$3-0,2 \mu \mathrm{m}$} & \multirow[b]{2}{*}{$<0,2 \mu \mathrm{m}$} \\
\hline & $>100 \mu \mathrm{m}$ & $\begin{array}{c}100-50 \\
\mu \mathrm{m}\end{array}$ & $50-30 \mu \mathrm{m}$ & $30-10 \mu \mathrm{m}$ & $10-5 \mu \mathrm{m}$ & $5-3 \mu \mathrm{m}$ & & \\
\hline $\mathrm{D}$ & $0.64 \mathrm{a}$ & $0.32 \mathrm{a}$ & $0.96 \mathrm{a}$ & $0.23 \mathrm{a}$ & $0.54 \mathrm{a}$ & $0.10 \mathrm{a}$ & $7.54 \mathrm{a}$ & $19.51 \mathrm{a}$ \\
\hline UD & $0.44 \mathrm{a}$ & $0.26 \mathrm{a}$ & $\begin{array}{c}0.89 \mathrm{~b}(\mathrm{p}< \\
0.028)\end{array}$ & $0.23 \mathrm{a}$ & $0.77 \mathrm{a}$ & $0.13 \mathrm{a}$ & $6.94 \mathrm{a}$ & $20.0 \mathrm{a}$ \\
\hline \multicolumn{9}{|l|}{ Tillage } \\
\hline NT & $0.43 \mathrm{a}$ & $0.26 \mathrm{a}$ & $0.93 \mathrm{a}$ & $0.25 \mathrm{a}$ & $0,86 a$ & $0,09 \mathrm{a}$ & $7.46 \mathrm{a}$ & $21.14 \mathrm{a}$ \\
\hline $\mathrm{CH}$ & $0.65 \mathrm{a}$ & $0.32 \mathrm{a}$ & $0.92 \mathrm{a}$ & $0.21 \mathrm{a}$ & $0.44 \mathrm{a}$ & $0.14 \mathrm{a}$ & $7.03 \mathrm{a}$ & $\begin{array}{c}18.35 b \\
(p<0,038 \\
)\end{array}$ \\
\hline
\end{tabular}

Soil pore size distribution for the $15-30 \mathrm{~cm}$ layer

\begin{tabular}{lcccccccc}
\hline D & $0.55 \mathrm{a}$ & $0.30 \mathrm{a}$ & $0.94 \mathrm{a}$ & $0.31 \mathrm{a}$ & $0.48 \mathrm{a}$ & $0.20 \mathrm{a}$ & $9.23 \mathrm{a}$ & $23.39 \mathrm{a}$ \\
\hline UD & $0.69 \mathrm{a}$ & $0.29 \mathrm{a}$ & $0.89 \mathrm{a}$ & $0.23 \mathrm{a}$ & $0.53 \mathrm{a}$ & $0.09 \mathrm{a}$ & $8.85 \mathrm{a}$ & $23.66 \mathrm{a}$ \\
\hline Tillage & & & & & & & \\
\hline NT & $0.75 \mathrm{a}$ & $0.32 \mathrm{a}$ & $0.90 \mathrm{a}$ & $0.21 \mathrm{a}$ & $0.37 \mathrm{a}$ & $0.11 \mathrm{a}$ & $8.94 \mathrm{a}$ & $23.13 \mathrm{a}$ \\
\hline $\mathrm{CH}$ & $0.49 \mathrm{a}$ & $0.27 \mathrm{a}$ & $0.94 \mathrm{a}$ & $0.34 \mathrm{a}$ & $\begin{array}{c}0.64 \mathrm{a}(\mathrm{p}< \\
0,087)\end{array}$ & $0.18 \mathrm{a}$ & $9.14 \mathrm{a}$ & $23.91 \mathrm{a}$ \\
\hline
\end{tabular}

Upon comparing drainage treatment's effects on soil pore sizes at the $0-15 \mathrm{~cm}$ soil layer, the $50-30 \mu \mathrm{m}$ pore size class was significantly impacted by soil drainage treatments $(\mathrm{p}<0.028)$ and drained treatments had significantly higher amount of 50-30 $\mu \mathrm{m}$ pore volume than the undrained plots. Having compared the effects of tillage treatments on soil pore size distribution, the pore size class of $<0,2 \mu \mathrm{m}$ clearly registered a very significant impact of soil tillage treatments. As a result, the NT treatments had significantly higher microporosity $(15.2 \%)$ than the $\mathrm{CH}$ plots in the surface soil of 0-15 cm layer (Table 3). This result was found $8 \%$ higher for the NT treatments against other tillage managements by Hernandez et al. (2019). The NT had higher storage pores than the $\mathrm{CH}$ treatments in the surface soil, while the opposite was true for the subsoil layer in the field. Shukula et al. (2003) reported higher storage and transmission pores in the surface soil of $0-10 \mathrm{~cm}$ thickness for the NTs from the KokomoCrosby soil series in Ohio.

The 15 to $30 \mathrm{~cm}$ layer of the soil has not shown any significant difference between the drained and undrained treatments for any pore size classes. As a result, mean pore size volumes were equal to each other for any pore size class pairs of the D and UD treatments in the subsoil. The pore size class of $10-5 \mu \mathrm{m}$ was marginally significantly influenced by soil tillage treatments $(p<0.087)$ where the $\mathrm{CH}$ plots had $72.9 \%$ more pore volume than the NT treatments for the sublayer of $15-30 \mathrm{~cm}$. Although the $\mathrm{CH}$ treatments had 1.56 times higher pore size volume for the $5-3 \mu \mathrm{m}$ pore size class than the NT treatments for the surface layer of the soil and the D treatments had 2.22 times greater volumes of the 5$3 \mu \mathrm{m}$ pore size class in the sublayer of $15-30 \mathrm{~cm}$ than the UD treatments, the difference between the treatment means was not significant. Moriera et al. (2016) observed that wetting and drying cycles were largely responsible for pore size distribution in crop rows, inter-rows and interposition between the row and the interrow position for the NT treatments. They found the change was predominately in the pore size class $>150 \mu \mathrm{m}$ on the rows and the effect of wetting and drying cycle changed when inter-rows had pore sizes $<3 \mu \mathrm{m}$. This meant their no-till treatments were conserving more water in the smaller pores and macropores were either broken down or dispersed naturally.

\subsection{Infiltration Rate and Cumulative Infiltration}

Initial water content had an important role in measuring soil infiltration rates in the treatments. Because the initial water contents of the treatments were different from each other at the time of infiltration tests in the field, the measured infiltration rates might not be expected to be significantly differentiated from each other. There were the measurement cases of infiltration during the test that the infiltration was very slow for the first 5 to 7 minutes. The water ponding depth in the inner ring was never let below 3 $\mathrm{cm}$ according to the stage signs prescribed on the wall of inner cylinder during the measurements The infiltration parameters produced from the measurements at each treatment were tabulated in the Table 4.

Table 4. Treatment effects on infiltration parameters of the soil

\begin{tabular}{|c|c|c|c|c|}
\hline $\begin{array}{l}\text { Treatments } \\
\text { Tillage- } \\
\text { Drainage }\end{array}$ & $\begin{array}{c}\text { CumI, } \\
\text { cm }\end{array}$ & $\begin{array}{c}\text { i, } \\
\text { cm.hr }\end{array}$ & $\begin{array}{c}\mathrm{S}, \\
\text { cmmin }^{-1 / 2}\end{array}$ & $\begin{array}{c}\text { A, } \\
\text { cm. } \\
\text { hr }^{-1}\end{array}$ \\
\hline $\mathrm{D}$ & $42.15 \mathrm{a}$ & $9.05 \mathrm{a}$ & $4.5 \mathrm{a}$ & $0.10 \mathrm{a}$ \\
\hline UD & $60.40 \mathrm{a}$ & $12.75 \mathrm{a}$ & $3.6 \mathrm{a}$ & $0.12 \mathrm{a}$ \\
\hline NT & $42.45 \mathrm{a}$ & $10.9 \mathrm{a}$ & $2.90 \mathrm{a}$ & $0.1 \mathrm{a}$ \\
\hline $\mathrm{CH}$ & $60.1 \mathrm{a}$ & $11.0 \mathrm{a}$ & $5.15 \mathrm{a}$ & $0.13 a$ \\
\hline
\end{tabular}

CumI: Cumulative infiltration depth, i: infiltration rate, $\mathrm{S}$ : sorptivity, A: transmissivity.

In order to characterize infiltration process, the field measurements were used to calculate soil sorptivity and steadystate infiltration rate (Table 4). The sorptivity part of Phillip's equation (Philip, 1957), $\mathrm{S}=\mathrm{I}(\mathrm{t}) / \mathrm{t} 1 / 2$ is called the capillary potential while the steady-state infiltration rate part is called gravity potential, At, (Parlange, 1971; Philip, 1957). The capillary part dominates at the beginning time of the infiltration, while the

1017 
gravity potential part persists at longer time as the $\mathrm{I}(\mathrm{t})$ reaches to an arbitrary value in infinity.

The evaluation of poorly estimating models that were fitted to the measured data from the treatments revealed that all treatment combinations for one particular replication produced negative transmissivity values. The undrained treatments, the NTUD and CHUD, were the least negative $(<0.002 \mathrm{~cm} . \mathrm{h}-1)$ and their negativity was not apparent in the statistical tests (Table 4). However, the drained treatments, the NTD and CHD, persisted to be negative in the statistical averaging. The least square-fit graphs were utilized to estimate soil sorptivity and steady-state infiltration rates rather than the measured original infiltration curves. The curve fitting (transforming to a log-log scale) of original data to the Philip's model produced very high R2 values for each treatment during the estimation (Akis, 1999). Generally, the steady-state infiltration rates were less than the soil Ks values for all treatments, meaning soils of the treatment were wettable enough and water intake was slow although storage pores and micropores were found significantly higher among the treatments (Table 3) for the surface soil. The wetting front was not deeper in the treatments where the steady-state infiltration rate was greater than the soil Ks. This was attributed to the relatively short elapsed times during water infiltration process of measurement, weak structural pores, and pore size distribution in the undrained treatments. As a result, the infiltration rate did not reach a steady state level where the gravity potential part of the Philip's equation was negative. Bughici and Wallach (2016) approached the result in their measurements and they observed infiltration rate did not reach the steady state because of the limited soil sample depth. Altough the Ksat values were smaller in the drained treatments than the ones in the undrained treatments, pore resistivity was higher against pore break-down than it was in the undreained soils.

The minimum and maximum time allowed for an infiltration test ranged between 42 and 100 minutes in the field. The only difference to the test duration occurred in the NTUD plots that took no more than 59 minutes. Since the commencement of the infiltration measurements, a 40-minute period has been enough to reach a virtual steady state infiltration levels in the soil. However, this has not guaranteed a complete saturation during the measurement. The least squared fit models estimated as high as 2.7, 2.8, 3.0, and 2.7 times higher initial infiltration rates for the CHUD, CHD, NTUD, and NTD than the observed values for each treatment, respectively. The NTD treatments showed higher level of pore connectedness so the instant infiltration rates were hardly mimicking a change over time and soil pores were assumed to store large amount of water. The optimized infiltration rates (Figure 1) illustrated that the drained treatments had higher (NTD $>$ CHD) initial and final infiltration rates than the undrained treatments (NTUD $>$ CHUD). This exact property of the cumulative infiltration depth holds for the optimized models in drained and undrained treatments for both tillage practices (Figure 2).

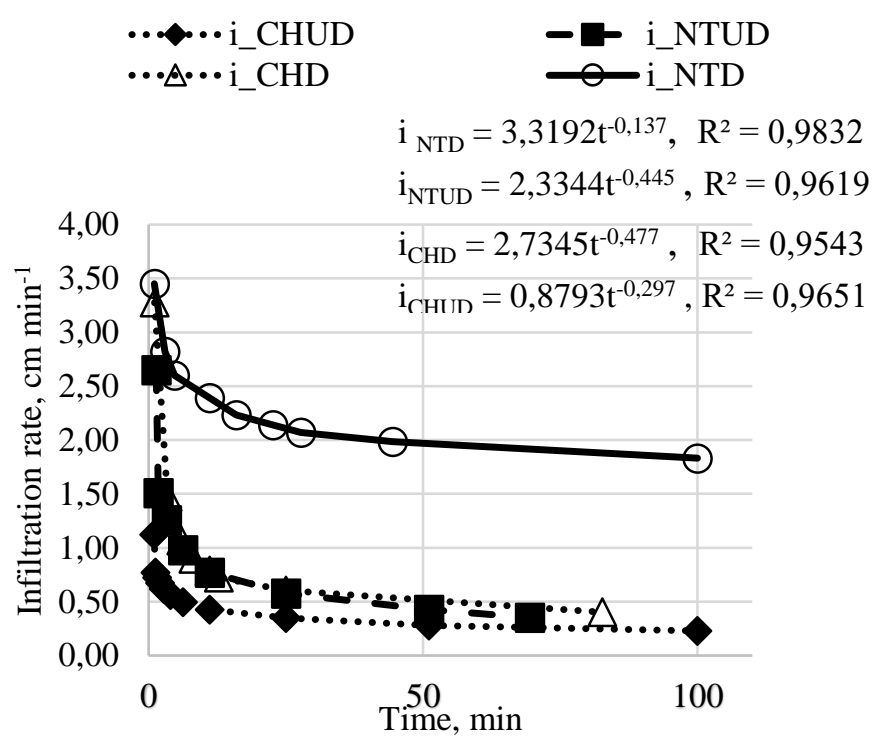

Figure 1. Typical optimized infiltration rate curves for the treatments in the research site

Drained plots were always higher in S values than the UD plots (4.5 versus $3.6 \mathrm{~cm} . \mathrm{min}-1 / 2)$ and the $\mathrm{CH}$ treatments were always higher than the NT treatments in soil sorptivity values (5.15 versus $2.90 \mathrm{~cm} . \mathrm{min}-1 / 2)$ for the 0 to $15 \mathrm{~cm}$ layer (Table 4). These results are consistent with (Abid and Lal, 2009). The UD versus the $\mathrm{D}$ treatments and the $\mathrm{CH}$ versus the $\mathrm{D}$ treatments registered $43.3 \%$ and $41.6 \%$ higher cumulative infiltration, respectively (Table 4 ).

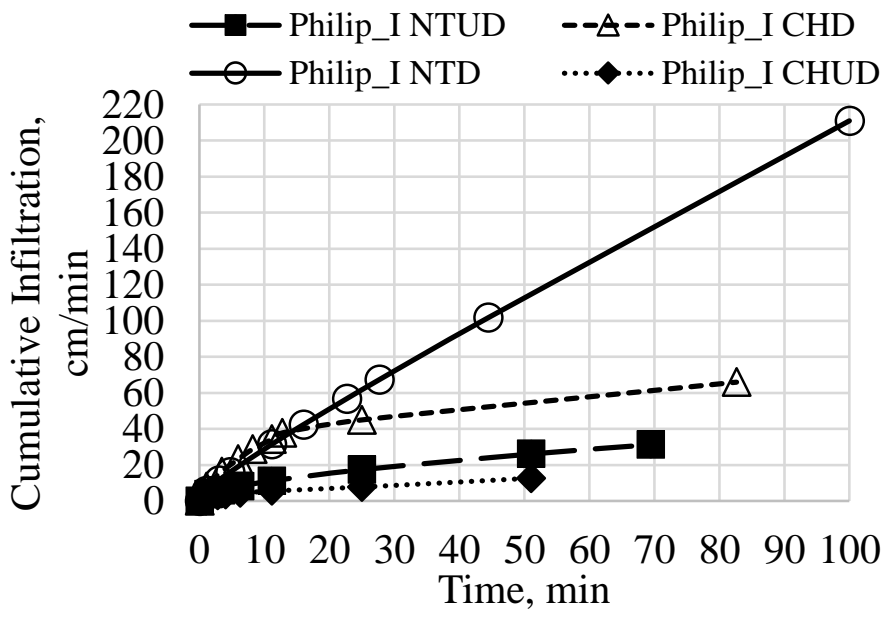

Figure 2. Typical optimized cumulative infiltration curves for the treatments in the research site

\subsection{The Infiltration Model Performance for Cumulative Infiltration Predictions}

The Philip's model predicted the infiltration rate and depth from moderate to excellent efficiency ( $\mathrm{NSE}=0.1$ to 0.9 and $\mathrm{RMSE}=0.5$ to $1.37 \mathrm{~cm} . \mathrm{hr}-1$ ) (Table 5). The statistical evaluation of the prediction characteristics of infiltration model of optimized versus estimated revealed that the efficiency and thus, the performance of the model in the CHUD treatments. The NSE was the highest $(\geq 0.90)$ for the CHUD tretments, while the predictions were less efficient for the NT treatments (NSE $\geq 0.102$ for drained 
and NSE $\geq 0.106$ for the undrained treatments) (Table 5). The prediction efficiency was medium in the CHD treatments with NSE $\geq 0.106$ and $\mathrm{RMSE}=1.37$. The NT treatments registered the lowest RMSE of $0.5-1.15$, while the RMSE ranged from 1.23 thru 1.37 for the $\mathrm{CH}$ treatments. As a result, the $\mathrm{CH}$ treatments were efficiently predicted by the infiltration model, while the NT model predictions were moderately efficient (Table 5). There are several reasons for this conclusion beside soil surface conditions, soil moisture content, residue amount on the surface soil, organic matter content, structural development, soil heterogeneity, and evapotranspiration. First of all, total durations of infiltration tests were not equal for each treatment in the field and some of the replications of each treatment test prevailed negative transmissivity, while graphically producing least- squared-fit models for the measurements. Since the negative gravity potential part is not considered a realistic value or is considered poor prediction of the gravity potential in long duration of the test, a correction can be performed on the estimated model through optimization so that the model turns into a positively structured time series equation of two-term Philip's model. In the light of this thinking, the poorest estimating models producing negative transmissivity from the treatments were employed to optimize infiltration model parameters so that a less-error prone infiltration value through the use of prediction capability of the model could be obtained and the measurements could be more representative of the infiltration process. Both of these objectives were achieved in the current study. Infiltration curves (Figure 1) prove that no negative values are possibilities in the prediction range of estimation of the optimized models for the treatments. Secondly, being poor quality of estimation models for graphical determination of the infiltration model parameters is sourced from inadequate elapsed time for the infiltration test. This problem occurred for one replica per treatment in the field and all of the particular replica registered negatively estimating transmissivity values for the infiltration model, while the other two replications for the treatments ( 8 out of 12 infiltration measurements) perfectly yielded positively structured sorptivity and transmissivity terms in the Philip's equation. This negativity is highly possible by forcing the least-squared-fit model to estimate beyond its prediction range, i.e., forcing the regression line to hit the y-axis and interpolating or extrapolating beyond the time-base of infiltration. In addition, the negative transmissivity values that were encountered in these poor models used in optimization process ranged from 0.03 to 0.18 for the CHD and the NTD, respectively, and averaging on the range equals to $0.09 \mathrm{~cm} . \mathrm{h}-1$ that corresponds to the values for the drained treatments (Table 4). The undrained treatments yielded transmissivity values between 0.02 and 0.22 for the NT and $\mathrm{CH}$ practices and average on the range was $0.12 \mathrm{~cm} . \mathrm{h}-1$, corresponding to $0.12 \mathrm{~cm} . \mathrm{h}-1$ for the undrained treatments (Table 4). The negative transmissivity value can be dismissed from the Philip's equation by adding opposite signed equal quantity of the same transmissivity value to each time series measurement in the given treatment. This process never impacts the sorptivity value at all. Finally, addition of a third time series term to the Philip's equation would improve the characterization of infiltration parameters as Kutilek and Kerjča (1987) model suggested. Khasraei et al. (2021) and Mahaparta et al. (2020) used three-term Philip equation and Mahaparta et al. (2020) also dismissed the negative transmissivity or the gravity potential values through field data optimization, while fitting their field data to the seven infiltration models. The Philip's model was most reliable in the shrubland vegetation with the confidence band width of approximately $4 \mathrm{~mm}$.min-1, more uncertain for sandy clay loam than sandy loam soil, and the most uncertain $(\sim 6.6$ mm.min-1) for the entire area rather than their grid area of $400 \mathrm{x}$ $400 \mathrm{~m} 2$ in estimating Ksat among estimation models they used. They also reported that less uncertainty models in estimating Ksat were as a result of being modified from the Philip model and Fodor et al (2011) also reported the Ksat resemblance as a result of a series of modified Philip equation.

\subsection{Validation and Prediction Accuracy of the Infiltration Model}

In the current study, a poor quality estimation model of infiltration tests was intentionally chosen to calibrate the model. Then, the rest of the two replications collected at the same time from the same treatments were used as validation dataset for the calibrated model. All of the optimized models for the treatment given in Table 5 improved the best, the parameter of initial infiltration rates. The optimized models predicted for 42 minutes because the poor models of estimation were out of 42-minute infiltration tests and therefore, the cumulative infiltrations are low but more rigid than the estimated ones. Besides, the whole time base of infiltration models is preserved in Figure 1.

Table 5. Parameters of estimated and optimized infiltration model.

\begin{tabular}{lcccccccc}
\hline Treatments & \multicolumn{7}{c}{ Philip Infiltration Model } \\
\hline & \multicolumn{3}{c}{ Estimated } & \multicolumn{5}{c}{ Optimized } \\
\hline NT-D & $\mathrm{i}_{\mathrm{i}}$ & $\mathrm{i}_{\mathrm{c}}$ & $\mathrm{I}$ & $\mathrm{i}_{\mathrm{i}}$ & $\mathrm{i}_{\mathrm{c}}$ & $\mathrm{I}$ & RMSE & NSE \\
\hline CH-D & 10.52 & 1.05 & 1.96 & 21.07 & 1.26 & 1.96 & 0.5 & 0.1 \\
\hline NT-UD & 22.10 & 2.34 & 8.21 & 46.37 & 2.34 & 8.66 & 1.37 & 0.4 \\
\hline CH-UD & 23.39 & 4.49 & 7.20 & 23.39 & 2.60 & 1.87 & 1.15 & 0.1 \\
\hline
\end{tabular}

NT-D:no-till and drained, CH-D: chisel-till and drained, NTUD: no-till and undrained, $\mathrm{CH}-\mathrm{D}$ : chisel till and undrained, ii: initial infiltration rate (cm.h-1), ic: constant infiltration rate $(\mathrm{cm} . \mathrm{h}-$
1), I: cumulative infiltration depth (cm), RMSE: Root Mean Squared Error, NSE: Nash-Sutcliffe Efficiency. 
The validation of the infiltration models for the treatments were tested with a new infiltration dataset to make sure of predicting an accurately representative value in the range of prediction model. The NT treatments showed the predicted and observed values explained the variance between the predicted and observed values with R2 of above $75 \%$ for drained sites and $79 \%$ for undrained sites, indicating validity of the predicted values were highly acceptable for the research site if these optimized models are used to estimate (Figure 3). Initial cumulative infiltration depth was higher $(3.72 \mathrm{~cm})$ for the NTUD than the ones for the NTD treatments $(1.84 \mathrm{~cm})$ (Figure 3$)$. Similarly, the slope of cumulative infiltration for the NTUD was greater than the ones for the NTD sites. The validation process produced correspondence between observed and predicted data of cumulative infiltration above $90 \%$ for the CHD and $84 \%$ for the CHUD sites. The initial cumulative depths of the $\mathrm{CH}$ treatments were almost the same 0.26 and 0.28 for the respective drained and undrained sites. The CHD treatments registered 3.99 times higher slope (0.1428) than those for the CHUD treatments (0.0358). Despite the higher initial accumulative infiltration depth in the CHUD than the CHD treatments, structural pores do not store the infiltration water as much water as it arrives at the pores. Most of the observed and predicted values lumps in the same area close to the origin of the validation graph, an indication of some proportion of the infiltrated water may not be stored and macropore breakdown and slaking can dominate in the CHUD treatments more than the CHD treatments. Besides, surface residue can intake some share of water and this effect may be persisting during infiltration test. Although initial cumulative infiltration depth is higher in the NTUD than the NTD treatments, the NTUD treatments can store more water because of the rigidity of structural pores against breakdown and slaking. This is indicated because of the correlations between observed and predicted values in a large range of water accumulation in the NTUD treatments. In general, the NT treatments have similar slopes for the cumulative infiltration depths, despite their low model efficiency (Table 4), while the $\mathrm{CH}$ treatments vary in their slopes for the cumulative infiltration, indicating less structural stability for the $\mathrm{CH}$ treatments.
NT-D
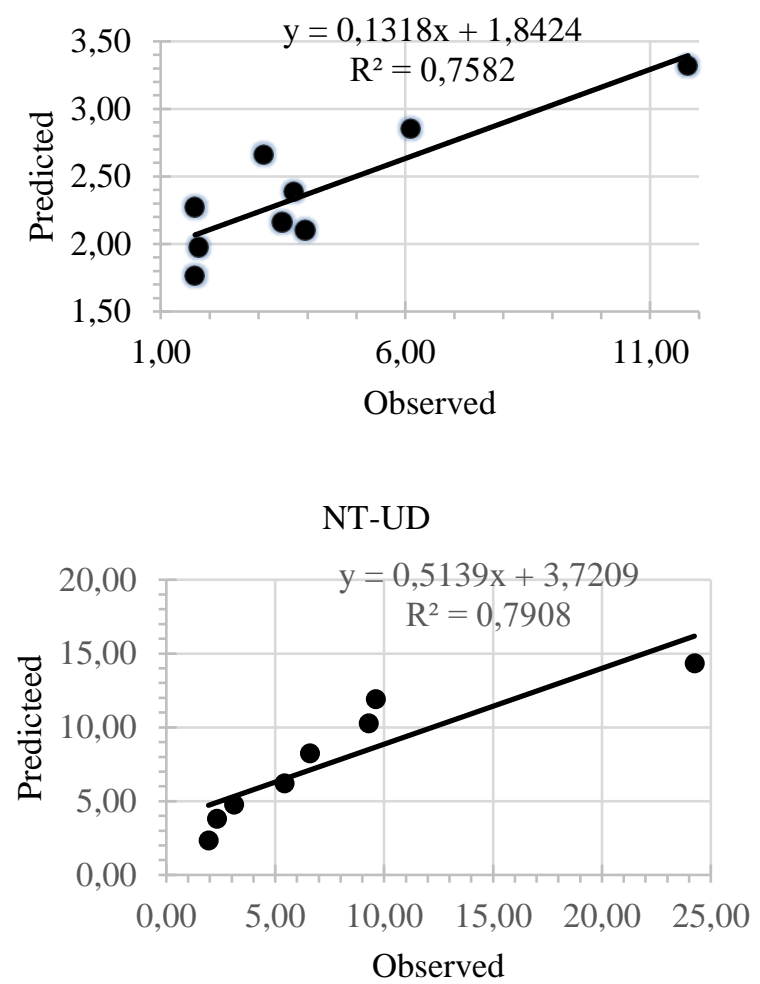

CH-D

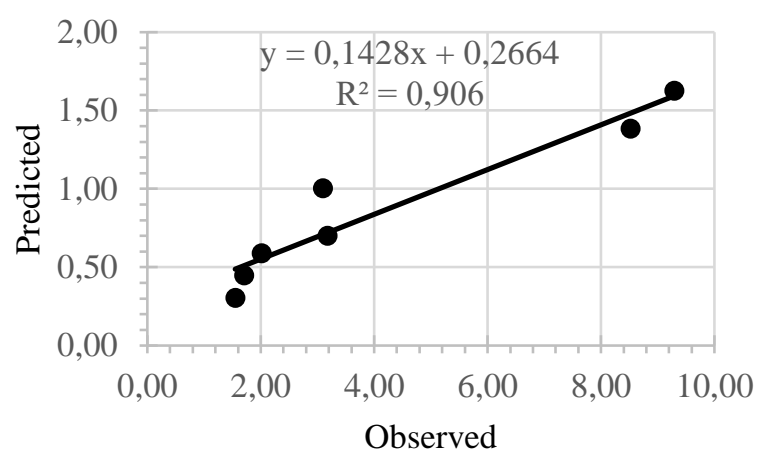

CH-UD

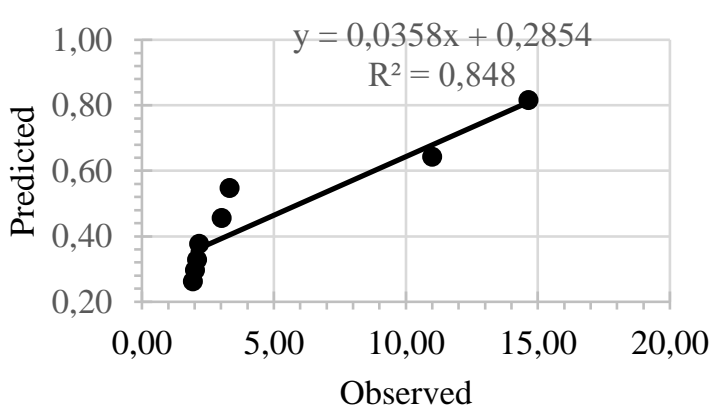

Figure

3. The validation of infiltration model for cumulative infiltration depth for each treatment

\section{Conclusions and Recommendations}

Soil tillage research was executed by the addition of soil drainage system to the research site at the Ohio State University's 
agricultural research farm at Kenny Road, Columbus, OH. Soil physical properties and infiltration was evaluated under different tillage and drainage management systems. The results of this study improved the comprehension of the changes impacted on soil physical properties and water transport and storage processes by soil tillage and drainage applications. Soil saturated hydraulic conductivity was the major driving force for soil water infiltration and drainage flows in the study. The results showed that, for the surface layer, the $\mathrm{CH}$ treatments had more macropore volume than the NT plots for the pressure head greater than and equal to $-6 \mathrm{kPa}$ and the pore volumes for the pressure head range from $-6 \mathrm{kPa}$ to $1500 \mathrm{kPa}$ were always higher for the NT than the $\mathrm{CH}$ treatments. These were the storage pore sizes ranging between 50 and $0.2 \mu \mathrm{m}$. The NT treatments included significantly higher amount of micropores $(21.17 \%)$ than the $\mathrm{CH}$ treatments $(18.35 \%)$, which proportionate $42.6 \%$ of the total porosity in the NT and $15.2 \%$ higher than the micropores in the $\mathrm{CH}$.

Pressure heads greater than and equal to $-6 \mathrm{kPa}$ produced greater macropore drained volumes in the NT treatments $(0.32)$ than the $\mathrm{CH}$ plots $(0.27)$ in the sublayer $(15-30 \mathrm{~cm})$. The pressure head range of -6 thru $-1500 \mathrm{kPa}$ drained more pore volumes for the $\mathrm{CH}$ treatments than the ones in the NT treatments. A greater amount of macropores in the $\mathrm{CH}$ rather than the NT at the surface soil of $0-15 \mathrm{~cm}$ thickness and greater volume of macropores in the NT rather than the $\mathrm{CH}$ at the subsoil depth of $15-30 \mathrm{~cm}$ is a strong indication of soil structural development and water retention properties in these treatments. This indicated that the NT treatments had well connected macropores that convey saturated flow to the tile drains and groundwater table. Therefore, the NT has a potential to capture more rainfall with higher infiltration capacity and to reduce soil sediment transport, erosion hazard, and runoff generation in the study area when compared to the $\mathrm{CH}$ treatments. In general, cumulative infiltration depth for the NT $(42 \mathrm{~cm})$ was smaller than the one from the $\mathrm{CH}$ treatments $(60 \mathrm{~cm})$ because of the smaller amount of macropores for the NT in the surface soil. However, the macropores in the CHs were not longlasting pores and they collapsed or degraded shortly after plant started to grow. Because the macropores are broken down or deteriorated, the storage pores and other pores (meso pores) may have been clogged. As a result, storage-, meso-, and micro-pores have totaled into a smaller amount in the $\mathrm{CH}$ treatments for the surface layer in comparison with the NT. This indicates that organic matter incorporation into structural development in the $\mathrm{CH}$ was lower than the one for the NT treatments. This may worsen organic matter decay a big problem for the environment in such a way that the higher amount of $\mathrm{CO} 2$ and other greenhouse gasses may evaporate from the $\mathrm{CHs}$ to the atmosphere although this was not covered in the scoop of this study. The NT proved to have significantly greater amount of storage pores than the macropores. None of the plots had a macropore percentage of 10 and greater in the study field. Therefore, the NT was preferable to the $\mathrm{CH}$ treatments to capture and store precipitation. The NT was always denser than the $\mathrm{CH}$ treatments and drained less water than the $\mathrm{CH}$ treatments for the surface soil. The $\mathrm{CH}$ treatments were more hydrologically conductive than the NT treatments. Once again, this was evident that more macropores due to earthworm burrows, root-based pores and fissures did not lead to longevity of macropores to convey water in the $\mathrm{CH}$ treatments against longlasting and well-structured macropores in the NT treatments. As a result, organic matter additions could be prescribed to improve structural stability and development indices in the $\mathrm{CH}$ treatments. The CHD and the CHUD treatments were always more conductive than the NTD and the NTUD treatments at both of the depths. Despite the fact that the UD treatments were hydraulically more conductive than the D treatments, they were significantly short in effective porosity, the pores that retain water against -10 $\mathrm{kPa}$ pressure head. In addition, the UD treatments had larger amount of storage pore volume in the pressure head range -6-1500 $\mathrm{kPa}$ rather than macropores. The UD treatments were always denser than the D treatments for the two soil depths except the CHUD treatments being the lowest of all bulk density values during the research period. Besides, the $\mathrm{CH}$ treatments registered always low bulk density values against the NT treatments for both the soil depths. The results showed that the UD treatments always had more micropore volumes than the ones for the $\mathrm{D}$ for both soil depths.

Optimization of the infiltration model reduced the error of measurements and converted the negative gravity potential to a positive quantity that always guaranteed a higher positive quantity of steady-state infiltration rate values than measured ones in the field. Model validation proved that predicted and observed values of infiltration rates and cumulative infiltration depths have corresponded to one another from moderately high to high degree of accuracy. As a result, optimization should always be performed if the infiltration measurements are poor or unrealistic about the field tests of infiltration. Infiltration rate and cumulative infiltration model predictions were from moderate to excellent efficiency with reasonable errors of estimations (RMSE between 0.5 and 1.37). In general, the $\mathrm{CHs}$ showed the highest efficiency of prediction while the NTs showed the lowest residual errors and these models predicted as accurate as $75-90 \%$.

Assessing the variability of soil physical properties and infiltration characteristics under conservation farming system facilitated modeling of infiltration and provided insights of details of infiltration processes in this study. The results of this study especially about soil physical and hydrological properties provide a ground, on which a field manager, hydrologist, and water management specialist can partition rainfall amount into hydrologic cycle components and develop a sound water budget for this conservation agricultural site. Water harvesting structures can also be designed based on these findings to improve and provide available water capacity for future cropping season.

\section{Acknowledge}

This research study was conducted in the Kenny Road Farm/Waterman Farm, Columbus, OH, in Soil Science, School of Environment and Natural Resources, Ohio State University, in forward to the USDA-supported project: Improving sub-surface drainage of clay soils, Project no: $\mathrm{OHO} 00835$, (https://portal.nifa.usda.gov/web/crisprojectpages/0098786improving-sub-surface-drainage-of-clay-soils.html).

\section{References}

Abid, M., \& Lal, R. (2009). Tillage and drainage impact on soil quality: II. Tensile strength of aggregates, moisture rentention and water infiltration. Soil Till. Res., 103,364-372.

Abid, M., \& Lal, R. (2008). Tillage and drainage impact on soil quality: I. Aggregate stability, carbon and nitrogen pools. Soil Till. Res., 100, 89-98.

Adeniji, F. A., Umara, B. G., Dibal, J. M., \& Amali, A.A. (2013). Validation of infiltration rates with soil texture. A laboratory 
study. International Journal of Engineering and innovative Technology, 3(2), 454-459.

Akis, R. (1999). Tillage and drainage impact on soil physical properties and nitrate movement in a silt loam soil in Ohio. MS Thesis. The Ohio State university, Columbus, Ohio, USA., 1-148.

Angelaki, A., Sakellariou-Makrantonaki, M., Tzimopoulos, \& C. (2013). Theoretical and experimental research of cumulative infiltration. Transp. Porous Meida, 100(2), 247-257.

Bahattacharyya, R., Prakash, V., Kundu, S., Srivistava, A.K., \& Gupta, H.S. (2009). Soil aggregation and organic matter in a sandy clay loam soil of the Indian Himalayas under different tillage and crop regimes. Agric. Ecosyst. Environ., 132,126134.

Blake, G. R., \& Hartge, K. H. (1986). Particle density. Methods of soil analysis: Part 1 physical and mineralogical methods, 5, 377-382.

Bouwer, H. (1986). Intake rate: cylinder infliltrometer. In: A. Klute (Ed.), Methods of Soil Analysis, Part I. Physical and Mineralogical Methods. Agronomy Monograph No. 9. Madison, WI, 825-844.

Bughici, T., \& Wallach, R. (2016). Formation of soil-water repellency in olive orchards and its influence on infiltration pattern. Geoderma, 262, 1-11.

Cassel, D. K., Nielsen, D. R. (1986). Field capacity and available water capacity. In A. Klute (ed.). Methods of Soil analysis. Part 1. Agronomy no 9. American Soc. of Agron. 901-926.

Carvalho, D.F., Eduardo, E.N., Almeida, W.S., Santos, L.A.F., \& Alvez, S. A. (2015). Water erosion and soil water infiltration in diffefrent stages of corn development and tillage systems. Rev. Bras. De Eng. Agric. E Ambiental, 19, 1076-1082.

Czyzyk, F., \& Swierkot, Z. (2017). Recharging infiltration of precipitation water through the light soil in the absence of surface runoff. J. Water L. Dev., 32, 25-30.

Dao, T.H. (1993). Tillage and winter wheat residue management effects of water infiltration and storage. Soil Sci. Soc. Am. J., $57,1586-1595$.

Dashtaki, S.G., Homaee, M., Mahdian, M.H., \& Kouchakzadeh, M. (2009). Site-dependence performance of infiltration models. Water Resource Management, 23, 2777-2790.

de Almedia, W.S., Panachuki, F., de Oliveria, P.T.S., da Silva Menezes, R., Sobrinho, T.A., \& de Carvalho, D.F. (2018). Effect of soil tillage and vegetal cover on soil water infiltration. Soil Tillage Res., 175, 130-138.

Derpesh, R., Franzluebbers, A.J., Duike, S.W., Reicosky, D.C., Koeller, K., Freidrich, T., Sturny, W.G., Sa, J, C.M., \& Weiss, K. (2014). Why do we need to standardize no-tillage research? Soil Till. Res., 137, 16-22.

Fodor, N., Sandor, R., Organus, T., Lichner, L., \& Rajkai, K. (2011). Evaluation method dependency of measured saturated hydraulic conductivity. Geoderma, 165, 60-68.

Franzluebbers, A.J. (2002). Water infiltration and soil structure related to organic matter and its stratification with depth. Soil Till. Res., 56, 1997-2005.

Freese, R.C., Cassel, D.K., \& Denton, H.P. (1993). Infiltration in a Piedmont soil under three tillage systems. J. Soil Water Conserv., 48, 214-218.

Goddard, T., Zoebisch, M., Gan., Y., Ellis, W., Watson, A., \& Sombatpaint, S. (2008). No-till farming systems. World Association of Soil and Water conservation (WASWC). Special Publication No 3.

Gopi, G., \& Shanmugasundaram, K. (2019). Philip's and GreenAmpt model capability ot estimate infiltration for soils of
Mahilambadi, Tamil Nadu State, India. Int. J. Chem. Stud., 7, 1426-1429.

Greenland, D.J. (1979). Structural organisation of soils and crop production. In: R. Lai and D.J. Greenland (ed.) Soil physical properties and crop production in the tropics. John Wiley and Sons, New York, 47-56.

Hernanedz, T.D.B., Slater, B.K., Corbala, R.T., \& Shaffer, J.M. (2019). Assessment of long-term tillage practices of two Ohio soils. Soil and Tillage Research, 186, 270-279.

Huang, M. Liang, T., Wang, L., \& Zhou, C. (2015). Effects of notillage systems on soil physical properties and carbon sequestration under long-term wheat-maize double cropping system. Catena, 128,195-202.

Irmak, S., Odhiambo, L.O., Kranz, W.L.E., \& Eisenhauer, D.E. (2011). Irrigation efficiency and uniformity and crop water use efficiency. University of Nebrasca-Lincoln Exttention. Biol. Syst/ Eng. Pap. Publ., 451.

Jastrow, J.D., \& Miller, R.M. (1991). Methods of assessing the effects of the biota on soil structure. Agric. Ecosyst. Env., 34, 279-303.

Jha, M. K., Mahapatra, S., Mohan, C., \& Pohshana, C. (2019). infiltration characteristics of lateritic vadose zone: field experiment and modeling. Soil and Tillage Research, 187, 219-234.

Kay, B.D. (1990). Rate of change of soil structure under different cropping systems. Adv. Soil Sci., 12,1-52.

Khasraei, A., Abyaneh, H.Z., Jovzi, M., \& Albaji, M. (2021). Determining the accuracy of different water infiltration models in lands under wheat and bean cultivation. Journal of Hydrology, http://doi.org/10.1016/j.jhyrol.2021127122

Klute, A. (1986). Water retention: laboratory methods. Methods of soil analysis: Part 1 Physical and mineralogical methods, 5, 635-662.

Klute, A., Dirksen, C. (1986). Hydraulic conductivity and diffusivity: laboratory methods. In: Klute, A. (Ed.), Methods of Soil Analysis-Part I- Physical and Mineralogical Methods. American Society of agronomy, Madison, 687-734.

Kutílek, M., Jendele, L., \& Panayiotopoulos, K.P. (2006). The influence of uniaxial compression upon pore size distribution in bi-modal soils. Soil and Tillage Research, 86, 27-37.

Kutílek M., \& Krejča M. (1987): A three-parameters infiltration equation of the Philip's type solution. Vodohospodářský časopis, 35: 52-61. (in Czech)

Lal, R., Shukula, M.K. (2004). Principles of Soil Physics. Marcel Dekker, New York, 716.

Lal, R., \& Fausey, N.R. (1993). Drainage and tillage effects on a Crosby-Kokomo soil association in Ohio IV. Soil physical properties. Soil Technol., 6, 123-135.

Lal, R., Logan, T.J., \& Fausey, N.R. (1989). Long term tillage and wheel traffic effects on a poorly drained mollic ochraqualf in North West Ohio. 2. Infiltrability, surface runoff, subsoil flow and sediment transport. Soil Till. Res., 14, 359-373.

Mahapatra, S., Jha, M.K., Biswal, S., \& Senapati, D. (2020). Assessing variability of infiltrarion charcteristics and reliability of infiltration midels in a tropical subhumid region of India. Sci. Rep., 10, 1-18.

McGarry, D., Bridge, B.J., \& Radford, B.J. (2000). Contrasting soil physical properties after zero and traditional tillage of an alluvial soil in the semi-arid subtropics. Soil Till. Res., 105115.

Messing, I., \& Jarvis, N.J. (1993). Temporal variation in the hydraulic conductivity of a tiled clay soil as measured by tension infiltrometers. Journal of Soil Science, 44, 11-24. 
Moriera, H. W., Tormena, C.A., Karlen, D. L., da Silva, A. P., Keller, Thomas, \& Betioli, E. Jr., (2016). Seasonal changes in soil physical properties under long-term no tillage. Soil and Tillage Research, 160, 53-64.

Nakijama, T., \& Lal, R. (2014). Tillage and drainage management effect on soil gas diffusivity. Soil Till. Res., 135, 71-78.

Osunbitan, J.A., Oyedele, D.J., \& Adekulu, K.O. (2005). Tillage effect on bulk density, hydraulic conductivity and strength of a loamy sandy soil in southwestern Nigeria, Soil Till. Res., 82, 57-64.

Parlange, J. Y. (1971). Theory of water-movement in soils: 2. One-dimensional infiltration. Soil Science, 111(3), 170-174.

Philip, J.R. (1957). The theory of infiltration. 4. Sorptivity and algebraic infiltration equations. Soil Sci., 84, 257-264.

Rajasekhar, M., Umabai, D., Krupavathi, K., Navyasai, I., \& Gopi, R. (2018). Development and comparison of infiltration models and their field validartion. Int. J. Curr. Microbiol. Appl. Sci., 7, 2691-2701.

Randall, G.W., \& Iragavarapu, T.K. (1995). Impact of long tillage systems for continuous corn on nitrate leaching to tile drainage. J. Env. Qual., 24, 360-366.

Rashidi, M, Ahmedbeyki, A., \& Hajiaghhaei, A. (2014). Prediction of soil infiltrationrate based on some physical properties of soil. American-Euroasian journal of Agricultural and Environmental Science, 14(12), 1359-1367.

Roseberg, R.J., \& McCoy, E.L. (1992). Tillage and traffic-induced changes in macroporosity and macropore community: Air permeability assessment. Soil Sci. Soc. Am. J., 56, 12611267.

Shkula, M.K., Lal, R., \& Ebinger, M. (2003). Tillage effects on physical ad hydrological properties of a typic argiaquoll in central Ohio. Soil. Sci., 168, 802-811.

Silva, S.G.C., Giarola, N.F.B., Sa, J.C.M., Tormena, C.A., \& da Silva, A.P. (2012). Temporary effect of chiseling on the compaction of a Rhodic Hapludox under no-tillage. R. Bras. Ci. Solo, 36, 547-555.

Soane, B.D., Ball, B.C., Arvidsson, J., Basch, G., Moreno, F., \& Roger-Estrade, J. (2012). No-till in northern, western and south-western Europe: A review of problems and opportunities for crop production and the environment, Soil and Tillage Research, 118, 66-87.

Soil Survey Stuff, (1996). Keys to Soil Taxonomy, $7^{\text {th }}$ ed. United States Department of Agriculture, Natural Resources Conservation Service, Washington, DC, USA., 644.

Sullivan, M. D. (1997). Dissolved organic carbon and soil solution $\mathrm{pH}$ as affected by drainage, tillage, depth and season in agricultural watershed. MS Thesis. The Ohio State university, Columbus, Ohio, USA., 1-121.

Thornley, J.H.M., \& Cannell, M.G.R. (2000). Managing forests for wood yield and carbon storage: a theoretical study. Tree Physiol., 20(7), 477-484.

USDA-NRCS, (2006). Official soil series descriptions. Soil Survey Division. In: http://ortho.ftw.nrcs;usda.gov/cgibin/osd/osdname.cgi. 